\title{
PERCEPTIONS OF EXECUTIVE PAYMENT ABUSE IN PUBLIC INSTITUTIONS
}

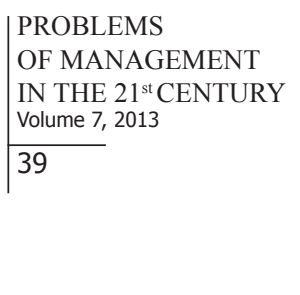

\author{
Tudor Pendiuc \\ Constantin Brancoveanu University, Pitesti, Romania \\ E-mail: tpdoru@gmail.com, cabinetprimar@primariapitesti.ro \\ Elena Carmen Lis \\ Pitesti City Hall, Romania \\ E-mail: ecarmen.prim@yahoo.com
}

\begin{abstract}
In the aftermath of the financial crisis, executive compensation abuse has been deeply criticized. Thus, the actuality of research is undeniable. The article highlights the importance of learning from other institutions' past and present executive compensation abuse experiences by presenting the participants ' shared experiences (having to do with executive compensation abuse) and by studying how participants perceive executive compensation abuse. The main objective of this research lies in exploring participants ' shared experiences concerning executive compensation abuse, as well as their perceptions, discrepancies and unsolved questions - presented within an ample, interconnected qualitative and quantitative methodological approach. A sample of 20 individuals was chosen for the triangulation method. From the resultant triangulation six new themes derive from the interview/questionnaire questions specifically referring to executive payment abuse namely: (a) ethics means distinguishing between right and wrong, (b) perspectives of ethical behaviour, (c) types of executive payment abuse, (d) the participant's perceptions of institution and colleagues.
\end{abstract}

Key words: executive compensation abuse, leader, public institution, perception.

\section{Introduction}

Due to the fact that the phenomenon of executive compensation abuse become alarming and widespread, executives must pay close attention to the manner in which their actions, behaviors, and decision-making affect employees, stakeholders and the institution itself.

Unethical leadership is defined "as behaviors conducted and decisions made by organizational leaders that are illegal and/or violate moral standards, and those that impose processes and structures that promote unethical conduct by followers. We now review then consequences and influences of unethical leadership." (Brown and Mitchell, 2010, p. 588) Thus, top managers engaging in, enabling, or fostering unethical practices in their institution do not show ethical leadership (Brown \& Trevino, 2005). For developing an ethical environment, top managers must set an example for employees to follow (Hamilton, 2006). Additionally, public managers who take advantage of their followers' unethical behaviour show unethical leadership (Pinto, 2008).

D. Johnston (2003) also studied problems resulting from corruption. According to him, profitability needs to be associated with sound, honest business practices since ethical top management proves financially sensitive. Another scholar, Gates (2004), has associated ethical top management with a growth in long-term market share whereas Kranacher (2006) stated that stakeholders interested in public institutions are jeopardised by scandal and corruption.

On the one hand, Verschoor (2006) observed that unethical behavior had a tedious im- 
Tudor PENDIUC, Elena Carmen LIS. Perceptions of Executive Payment Abuse in Public Institutions

PROBLEMS

OF MANAGEMENT

IN THE $21^{\text {st }}$ CENTURY Volume 7, 2013

pact on the success of an institution. Thus, in case ethical problems persist, the capacity of an institution to attract and maintain desirable employees diminishes (Verschoor, 2006).

When studying the motivations why a public manager would engage in unethical behaviors resulted in a variety of reasons (Felsberg, 2005). Leap (2008) offered an in-depth discussion referring to human features connected with ethically challenged public managers. The most important features of unethical executives include "(1) placing financial self-interests above all else, and (2) showing little concern for followers" (Leap, 2008, p. 23).

Donaldson's (2008) tried to implement proactive actions in favor of combating an unethical business environment. He also suggested a pro-management theory in order to limit unethical acts and behaviors between CEOs. The scholar considered that principles of stewardship must surpass a leader's personal ambition. According to Donaldson (2008) ethical education must not be obligatory, since unethical executive behavior is the outcome of improper interpretation. There are some merits which can be attributed to Donaldson but one could support the opinion that persons do learn through proper training techniques. Therefore, his argument proved incorrect as ethics can also be shared and learned just as other values.

\section{Problem of Research}

Generally, there is a widespread problem regarding executive compensation abuse, most of the time having to do with a lack of executive processes directed towards discouraging this particular abuse (Strier, 2007; Keller \& Stocker, 2008). According to Micewski and Troy (2007) leaders, executives must behave ethically, respectively, must perform in the benefit of the stakeholders and employees of the institution. They also offer an example in this respect.

The assessed thematic features sets are: (1) participants' knowledge of concepts; (2) institution transparency; (3) causes and effects of executive compensation abuse; and (4) participants' advice, recommendations as well as shared insight.

\section{Research Focus}

The most important aim of the research pertained to the lack of governance processes toward stopping or discouraging executive compensation abuse by identifying lived experience patterns as experienced by participants.

The below open-ended research questions will be used to gather responses for developing topic awareness among research participants:

1. What are the participants' shared experiences, having to do with executive compensation abuse?

2.How do participants perceive the executive compensation abuse?

The main purpose of this research was to analyze the experiences of several stakeholders who had encountered such executive compensation abuses.

First, the literature analysed denoted a necessity for system reforms (Friedrichs, 2009; T. Grant \& Grant, 2008). Second, researches did not have a general consensus or agreement regarding, on the one hand, specific causes and on the other hand, solutions to every ethical issue that leaders might be facing, such as moral responsibility, moral differentiation and ethical work culture. According to the literature review, public leaders can be held responsible for encouraging socially acceptable, ethical work places (Gates, 2004; Jennings, 2007; Prewitt, 2003). 


\section{Methodology of Research}

\section{General Background of Research}

The triangulation method represents the combination between qualitative and quantitative methodologies used in the research of one phenomenon. The qualitative and qualitative phenomenological researches are aiming at the study of the experienced incidents of a certain sample in relation to executive compensation abuse. The participants to the research revealed manners in which governance processes might stimulate fair, ethical compensation at work. Therefore, the executive compensation abuse issue is investigated "from the perspective of those who experience" it (Collingridge \& Gantt, 2008, p. 393).

\section{Sample of Research}

In the sample were analyzed label variables, among which mention: gender, age, education background, and work position held by the responder. All these variables were carefully considered in order to have an overview of the surveyed population (the target audience). For reasons of space, only the gender variable is presented.

According to the data, the investigated target group consists of $70 \%$ male and $30 \%$ female. Respondents

\section{Instrument and Procedures}

The current qualitative study included 8 focused questions meanwhile the quantitative research implied 12 questions, out of which 4 were for the demographic data of the responders. Both researches were used for exploring participant experiences with executive payment abuses in the workplace. The hypotheses of the quantitative research were the following: HS1: Executive compensation abuse highly affects employee morale and business ethics (experiences) and HS2: Generally, leaders abuse the business system for their personal gain.

\section{Data Analysis}

Data clustering for this research resided in locating and grouping together the similarities (for instance, themes) among shared experiences of research participants (Moustakas, 1994).

In the quantitative research, two features were central: experience and perception. Thus, the items 5 to 12 from the quantitative questionnaire are based on these two features, as follows:

Table 1. Feature analysed.

\begin{tabular}{ll}
\hline & Feature analysed \\
\hline Item 5 & Experience respondents \\
\hline Item 6 & Perception respondents \\
\hline Item 7 & Experience respondents \\
\hline Item 8 & Experience respondents \\
\hline Item 9 & Experience respondents \\
\hline Item 10 & Perception respondents \\
\hline Item 11 & Experience respondents \\
\hline Item 12 & Perception respondents \\
\hline
\end{tabular}


Tudor PENDIUC, Elena Carmen LIS. Perceptions of Executive Payment Abuse in Public Institutions

PROBLEMS

OF MANAGEMENT

IN THE $21^{\text {st }}$ CENTURY Volume 7, 2013

In the qualitative research, the next four thematic feature sets represented a core emphasis of the overall semi-structured interview methodology:

1. Participant proficiency of concepts;

2. Transparency of the institution;

3. Causes and effects regarding the executive payment abuse; and, last but not least

4. Participant advice, recommendations, and shared insight.

At the end of the qualitative study, six new themes were revealed.

\section{Results of Research}

Qualitative research regards a holistic approach of the respondents experience regarding the executive compensation abuse.

There were opened and no restraints discussions regarding the leader's abuse inside the institutions.

Questions to the respondents were applied personally and implied giving the information regarding the leader's abuse.

For the first hypothesis, "Executive compensation abuse highly affects employee morale and business ethics" were made a number of five correlations.

Table 2. Correlation between item 5 and item 3.

\begin{tabular}{llll}
\hline & & Item $\mathbf{5}$ & Item $\mathbf{3}$ \\
\hline Item $\mathbf{5}$ & Pearson Correlation & 1 & $0.527^{\text {** }}$ \\
\hline & Sig. (2-tailed) & & 0.000 \\
\hline Item $\mathbf{3}$ & $\mathrm{N}$ & 20 & 90 \\
\hline & Pearson Correlation & $0.527^{\text {**}}$ & 1 \\
\hline & Sig. (2-tailed) & 0.000 & \\
\hline
\end{tabular}

** Correlation is significant at the 0.01 level

Table 3. Correlation between item 7 and item 1.

\begin{tabular}{llll}
\hline & & Item 7 & Item 1 \\
\hline \multirow{2}{*}{ Item 7} & Pearson Correlation & 1 & $0.419^{* *}$ \\
\cline { 2 - 4 } & Sig. (2-tailed) & & 0.000 \\
\cline { 2 - 4 } & $\mathrm{N}$ & 20 & 20 \\
\hline \multirow{2}{*}{ Item 1} & Pearson Correlation & $0.419^{* *}$ & 1 \\
\cline { 2 - 4 } & Sig. (2-tailed) & 0.000 & \\
\cline { 2 - 3 } & $\mathrm{N}$ & 20 & 20 \\
\hline
\end{tabular}

** Correlation is significant at the 0.01 level 
Table 4. Correlation between item 8 and item 3.

\begin{tabular}{llll}
\hline & & Item 8 & Item 3 \\
\hline Item 8 & Pearson Correlation & 1 & $0.539^{* *}$ \\
\hline & Sig. (2-tailed) & & 0.000 \\
\hline Item 3 & $\mathrm{N}$ & 20 & 20 \\
\hline & Pearson Correlation & $0.539^{* *}$ & 1 \\
\hline & Sig. (2-tailed) & 0.000 & \\
\hline $\mathrm{N}$ & 20 & 20
\end{tabular}

** Correlation is significant at the 0.01 level

Table 5. Correlation between item 9 and Item 3.

\begin{tabular}{llll}
\hline & & Item 9 & Item 3 \\
\hline \multirow{2}{*}{ Item 9} & Pearson Correlation & 1 & $0.362^{\text {** }}$ \\
\cline { 2 - 4 } & Sig. (2-tailed) & 0.000 \\
\cline { 2 - 4 } & $\mathrm{N}$ & 20 & 20 \\
\hline \multirow{2}{*}{ Item 3 } & Pearson Correlation & $0.362^{* *}$ & 1 \\
\cline { 2 - 4 } & Sig. (2-tailed) & 0.000 & 20 \\
\hline & $\mathrm{N}$ & 20 & \\
\hline
\end{tabular}

** Correlation is significant at the 0.01 level

Table 6. Correlation between item 11 and item 3.

\begin{tabular}{llll}
\hline & & Item 11 & Item 3 \\
\hline \multirow{2}{*}{ Item 11 } & Pearson Correlation & 1 & $0.354^{* *}$ \\
\cline { 2 - 4 } & Sig. (2-tailed) & & 0.001 \\
\cline { 2 - 4 } & $\mathrm{N}$ & 20 & 20 \\
\hline \multirow{2}{*}{ Item 3 } & Pearson Correlation & $0.354^{* *}$ & 1 \\
\cline { 2 - 4 } & Sig. (2-tailed) & 0.001 & 20 \\
\cline { 2 - 4 } & $\mathrm{N}$ & 20 & 20 \\
\hline
\end{tabular}

** Correlation is significant at the 0.01 level

Based on the correlations made, one can state that executive compensation abuse affects the employees' morale, and for proving this, significant correlations were made. Thus we can say that the first hypothesis executive compensation abuse highly affects employee moral and business ethics was confirmed. follows:

To verify the second hypothesis a total of three significant correlations were done, as it 
Tudor PENDIUC, Elena Carmen LIS. Perceptions of Executive Payment Abuse in Public Institutions

PROBLEMS

OF MANAGEMENT

IN THE $21^{\text {st }}$ CENTURY

Volume 7, 2013

Table 7. Correlation between item 6 and Item 4.

\begin{tabular}{llll}
\hline & & Item 6 & Item 4 \\
\hline \multirow{2}{*}{ Item 6 } & Person Correlation & 1 & $0.351^{\text {** }}$ \\
\cline { 2 - 4 } & Sig. (2-tailed) & & 0.001 \\
\cline { 2 - 4 } & $\mathrm{N}$ & 20 & 20 \\
\hline \multirow{2}{*}{ Item 4 } & Person Correlation & $0.351^{\text {** }}$ & 1 \\
\cline { 2 - 4 } & Sig. (2-tailed) & 0.001 & 20 \\
\cline { 2 - 4 } & $\mathrm{N}$ & 20 & \\
\hline
\end{tabular}

** Correlation is significant at the 0.01 level

Table 8. Correlation between Item 10 and Item 7.

\begin{tabular}{llll}
\hline & & Item 10 & Item 7 \\
\hline Item 10 & Person Correlation & 1 & $0.414^{* *}$ \\
\hline Sig. (2-tailed) & & 0.000 \\
\hline Item 7 & $\mathrm{~N}$ & 20 & 20 \\
\hline & Person Correlation & $0.414^{* *}$ & 1 \\
\hline & Sig. (2-tailed) & 0.000 & \\
\hline & $\mathrm{N}$ & 20 & 20
\end{tabular}

** Correlation is significant at the 0.01 level

Table 9. Correlation between item 12 and Item 4.

\begin{tabular}{llll}
\hline & & Item 12 & Item 4 \\
\hline \multirow{2}{*}{ Item 12 } & Person Correlation & 1 & $0.389^{* *}$ \\
\cline { 2 - 4 } & Sig. (2-tailed) & & 0.000 \\
\cline { 2 - 4 } & $\mathrm{N}$ & 20 & 20 \\
\hline \multirow{2}{*}{ Item 4} & Person Correlation & $0.389^{* *}$ & 1 \\
\cline { 2 - 4 } & Sig. (2-tailed) & 0.000 & \\
\cline { 2 - 4 } & $\mathrm{N}$ & 20 & 20 \\
\hline
\end{tabular}

** Correlation is significant at the 0.01 level

Following the conducted correlations, the second hypothesis was confirmed as well. In all the methodological approach the themes resulted and the hypothesis of the research pointed out an important aspect. Employees are sensitive to executive compensation abuses of any nature. Unfortunately there is little protection against this and one major part can be played by the psychological side and the manner how each individual was brought up. 


\section{Results of the Qualitative Research}

The researches can contribute toward improving present public management processes or establishing newer guidelines for the effective management of leader payment abuses thus being encouraged the fair, ethical compensation in the workplace.

From the triangulation resulted that, there are six new themes that derived from the interview/questionnaire questions specifically referring to executive payment abuse namely: (a) ethics means knowing right from wrong, (b) perspectives of ethical behavior, (c) types of executive payment abuse, (d) participant perceptions on institution and colleagues, (e) how payment abuse impacted employees, and (f) transparency is imperative.

The patterns revealed in the six newly discovered themes addressed the below study questions:

1. What are the participants' shared experiences, having to do with executive compensation abuse?

2. How do participants perceive the executive compensation abuse?

Participants' lived experiences were the first emphasis found in (d) participant perceptions on institution and colleagues, and (e) how payment abuse impacted employees (both personally and professionally).

Participants' perceptions of executive payment abuse were addressed under (a) ethics is knowing right from wrong, (a) ethics means knowing right from wrong, (b) perspectives of ethical behavior, (c) types of executive payment abuse, and (f) transparency is imperative.

Theme 1: Ethics means knowing right from wrong. In the literature, ethics was defined by Robin (2009) as behaving so that one is able of resisting causing harm to others in spite of the presence of favorable conditions; meanwhile Wren (2005) stated that ethics represent practices implemented for perpetuating a civilized world. For Bannon, Ford, \& Meltzer, (2010), public leaders are responsible for business ethics.

Thirteen participants $(65,0 \%)$ interviewed in the study have seen ethics as the capability to distinguish right from wrong in an individual's pursuit of moral excellence. Respondent 3 considered ethics as "knowing the difference existing between right and wrong," meanwhile Respondent 17 added "It represents the difference existing between honesty and dishonesty. The difference between right and wrong."

The findings stated that public executives have a moral obligation first of all to distinguish between right and wrong, and second, to proactively quest for ethically sound actions, behaviors, as well as decisions.

Theme 2: Descriptions of ethical behavior. Bruhn (2009) considered public leaders might find it difficult to differentiate between ethical and unethical behaviors. Most of participants in the research took an opposite approach in the description of ethical and unethical behaviors. From the 20 participants interviewed in the research, 19 (95\%) presented usual examples to convey a proficient understanding of the ethical behavior concept and $13(65 \%)$ participants gave examples regarding unethical actions.

Participant 2 said, "I assume an individual's moral, means how he/she is raised or brought up. The individuals are going to do the right thing to do in the case they were raised right. For instance, you get out of the parking lot and find a wallet down there, you look inside it to find out the owner's name or address, and let's consider there's like 500 Euros in it; if you behave unethically, you would take the money and leave the wallet, but if you behave ethically, than you would turn the wallet to police or call the owner or something else..."

Participant 10 responded, "Not stealing and behaving honestly," and Participant 14 said, "I struggle with that. One more time, I think it's doing the right thing, knowing the difference between right and wrong, behaving honestly, treating individuals fairly, and this is what I think ethical behavior means. Always what's right over wrong. Generally, individuals should be born with that, but this is not at all true since prisons are full. These results prove that flawed reasoning exists with regards to confusion among top leaders since the lower ranking employees 
PROBLEMS

OF MANAGEMENT

IN THE $21^{\text {st }}$ CENTURY Volume 7, 2013

46

proved little difficulty the comprehension and description of ethical and unethical actions, behaviors as well as decisions.

Theme 3: Types of executive compensation abuse. Every time that an executive public manager puts his/her personal and financial interests above the institution and its employees, a type of leader payment abuse has occurred. The qualitative research presented two initial methods whereby each person described direct experiences with executive payment abuse at their jobs. Accordingly, nineteen responders out of twenty (95\%) considered that systematic abuse represented a primary means that executive public leaders use in order to circumvent organizational systems. Among them, abuses directed against employees were claimed to be major contributors to this phenomenon according to the remaining 11 participants (55\%). For instance, the second participant responded, "I have a feeling that it's something that public top management or department heads or nobody's going to do a thing . . .whenever somebody makes people work additional hours and does not pay them for these extra hours or when public top management tries to find a way into ... for example, manipulating the contracts in such a manner that it looks good on the general situation for getting higher wages. All these actions mean manipulating the system somehow. The outcome is that, I would say, they get more money in their bank accounts, the employees' payment is not increasing in spite of extra hours worked and thus, the morale is lower. As I said, this is all about the manipulation of the system in such a manner that money winds up in public top management's accounts.

Participant 3 answered, "Yes. Public managers that line their accounts at the expense of employees."

The research participants cited two essential methods of direct experience with public leader compensation abuse. Ten of the responders $(n=10)$ claimed their experiences with executive payment abuse in the workplace took place through corporate policies and lack of honesty. The rest of $50 \%$ of respondents $(n=10)$ described the manner in which executives had manipulated employee payment and benefit systems for their own gain. Participant 1 stated,

"The top leaders.... Some of them would be capable of moving services from their department and then transfer it to another department in order to increase their profits, although by doing this would lower the gross of another public manager, and thus, they would get the bonus at the expense of the other public manager who, at the best would get a smaller bonus.

These findings prove that leader compensation abuse is prevalent and widely spread due to the fact that public governance processes are either not sufficient or do not exist at all. Thus, employees are possible easy targets for managers to manipulate through abuses directed towards employees. One motivation why abuses directed towards employees seldom take place is that the employees could be low ranking and lacking any major input into the decision-making processes of the institution or consequences thereof .

Theme 4: Responders observations regarding the institution and employees. The responders in this research were asked to share some of their experiences regarding the institution and its' employees after observing executive payment abuse in the workplace. Fifteen responders $(75 \%)$ perceived lower morale and higher stress among employees. Participant 19 said,

"Well I kind of realized that the morale was diminishing among the colleagues, the workers. You have a lot of employees who would ... you know, there was an increase of absenteeism. There were plenty of job injuries on the job or people would abuse this type of system simply due to the fact that they had the feeling of being abused themselves."

Theme 5: How payment abuse affected me. According to Nash (2010), work-related stress on employees proved being highly costly (around $\$ 300$ billion) and damaging to the whole well-being of American businesses. Stressors related to work negatively impact employees' health, morale, as well as productivity and profitability of the institution (Nash, 2010). Responders described two major negative consequences which affected their personal lives due to having lived executive payment abuse phenomena at job.

There are two major types of influence: on the personal life and on professional life. As far as the personal life is concerned, thirteen interviewees $(65 \%)$ referred to stress as a result 
from experiences with executive payment abuses at job as an essential factor that affects in a negative manner their personal lives. 11 responders $(55 \%)$ shared examples of personal financial crises as a result of leader payment abuse. Participant 11 observed: "Monetarily. The end. Sad but also frustrated. I was forced into getting a new job and as a consequence, of a totally different position at another institution." Participant 13 noticed, "Loosing the job, personally as far as I'm concerned. I could add some depression, fear and stress - plenty of stress-mainly at the point of them actually shutting down."

As far as the influence on professional life is concerned, the volunteers in the research shared how public leader payment abuse had impacted their professional lives. 11 participants at the interview (55\%) claimed noticeable differences through lower motivation and job satisfaction, these two representing direct consequences of experiencing payment abuse at the job. Participant 15 said,

"From the professional point of view, I don't like my job as much as I used to, anymore due to the fact that I do have some negative feelings. Accordingly professionally, I consider that a happy civil servant represents a profitable employee. But I'm not sure anymore. If the civil servants are scared that tomorrow they may not have a job, they need to work pretty hard as well, so this is also a method to make them work hard! I use to think that I can get burned out quite quickly - I know this. Daily, I can't bear to be forced and forced and forced. But there is no escape for me." Participant 20 stated,

"I do my best so that it does not affect my work. I am pretty proud of myself and my work. I must tell you, sometime, I ask myself: How hard am I doing this? What is the reason for doing this? Thus, although I try not to, I think it would be a lie if I said that it had no impact on me, or on my colleagues."

Theme 6: Transparency is imperative. In an institution, transparency represents public governance and this is imperative in the encouragement of ethical actions, behaviors, and decision-making at work. The participants in this research addressed personal knowledge of whether their institutions had in place formal codes of ethics or policies meant against public leader payment abuse. In spite of having lived executive payment abuse at the job, half of the respondents $(50 \%)$ confirmed that their organizations had codes of ethics or policies run in order to discourage this phenomenon. Eight $(40 \%)$ of the 20 participants in the research were not aware or did not remember if their institutions had formal codes or policies, at all. Only two individuals $(10 \%)$ stated the institution where they had experienced executive compensation abuse had no code of ethics or policies to address this issue. Answering to whether the institution had a formal code of ethics or policies implemented for preventing executive payment abuse, the first Participant stated,

"Yes, there was a booklet with indications but I don't know. . . . All the employees were supposed to follow these indications, I mean, they needed to be applied by all of us. And it must have been. . . There was a certain code of ethics and how one should have followed certain procedures and all the rest. The public manager just simply didn't take it into consideration."

Participant 2 noticed, "No, the institution had no policies whatsoever or anything that sounded like a code of conduct to prevent executive payment abuse." Participant 3 answered, "Yes, but the top managers were hardly paying any attention to these policies. These policies used to be changed at the will of leaders"; meanwhile, Participant 11 said simply:

"No."

However, to have formal and just policies in practice is by no means sufficient to prevent unethical actions, behaviors, or decisions (Currell \& Bradley, 2010). As Currell and Bradley (2010) put it, the use of enforcement strategies for the reinforcement of public governance initiatives is a means of actively fighting against ethical indiscretions at job. 12 interviewees $(60 \%)$ considered that the creation and adoption of formal and just policies with enforcement as an initial method to curtail or stop top management payment abuse in the workplace.

Participant 15 considered,

"I consider that the most important thing would be if everything were wide-open and if 
Tudor PENDIUC, Elena Carmen LIS. Perceptions of Executive Payment Abuse in Public Institutions

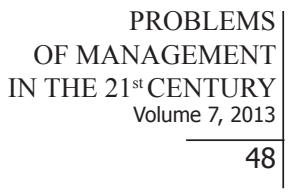

no one would hide information. I don't understand the reason for doing this, maybe they wanted to keep it for the directors or public executives but however, data was hidden from the employees. And it is my opinion that the employees and all the rest of the stakeholders must know. I think they have the right to know in order to be able to see every aspect of their working situation and make the right decisions."

These findings proved that there are major gaps having to do with to transparency within an institution and its employees or stakeholders due to the fact that employees seem ignorant of public governance initiatives aimed at managing workplace ethics.

\section{Conclusions}

The responders in the research answered to interview and questionnaire questions referring on perceptions and lived experiences with regards to top public management payment abuse. The persons involved in the study cited various experiences with regards to leader compensation abuse at work. The 20 responders in the present research also shared their insights with regards to improving business ethics and deterring top management payment abuse. Information gathered from 20 semi-structured interviews and questionnaires with employees offered, as seen above, six new themes.

Scholars referred to the next conditions for top management payment abuses in the workplace: (a) not sufficient or the lack of corporate governance processes, (b) top management failure in honoring ethical obligations to other persons involved in the institution. The outcomes of the research indicated top managers need to pay closer attention to the manner how their actions, behaviors, and decisions impact stakeholder groups, especially lower level employees. Participants in the hereby research showed adverse effects which resulted from top management payment abuses through executive actions, behaviors, and decisions. The findings from the research could lead towards the improved of management with regards to public executive payment abuses in the same time, establishing fair, ethical payment for employees.

\section{References}

Bannon, S., Ford, K., \& Meltzer, L. (2010). How to instill a strong ethical culture. The CPA Journal, 80 (7), 56-58.

Bogle, J. (2008). Reflections on CEO compensation. Academy of Management Perspectives, 22 (2), 21 25.

Brown, Michael, E., \& Marie, S. Mitchell (2010). Ethical and Unethical Leadership: Exploring New Avenues for Future Research. Business Ethics Quarterly, 583-616.

Brown, M. E., Trevino, L. K., \& Harrison, D. A. (2005). Ethical leadership: A social learning perspective for construct development and testing. Organizational Behavior and Human Decision Processes, $97,117-134$.

Bruhn, J. (2009). The functionality of grey area ethics in organizations. Journal of Business Ethics, 89, 205-214.

Collingridge, D., \& Gantt, E. (2008). The quality of qualitative research. American Journal of Medical Quality, 23, 389-395.

Currell, D., \& Bradley, T. (2010). Finding and fixing corporate misconduct. Risk Management, 57 (3), 33-36.

Donaldson, L. (2008). Ethics problems and problems with ethics: Toward a pro management theory. Journal of Business Ethics, 78, 299-311.

Friedrichs, D. (2009). Exorbitant CEO compensation: Just reward or grand theft? Crime, Law and Social Change, 51, 45-72.

Felsberg, E. (2005). Understanding retaliation and whistle-blowing claims. Employment Relations Today, $32,91-96$.

Gates, J. (2004). The ethics commitment process: Sustainability through value-based ethics. Business \& Society Review, 109, 493-505.

Grant, T., \& Grant, G. (2008). Can regulations curb excessive executive pay? Strategic Finance, 90 (3), 31-39. 
Hamilton, S. (2006). Sarbanes-Oxley will make little difference: Understanding the real reasons for corporate failure. Perspectives for Managers, 135, 1-4.

Jennings, M. (2007). When you have made a mistake. Corporate Finance Review, 11 (5), 44-49.

Johnston, D. (2003). Building trust. Organisation for Economic Cooperation and Development: The OECD Observer, 240/241, 3.

Keller, C., \& Stocker, M. (2008). Eyeing executive compensation. National Law Journal, 31 (12), S1.

Kranacher, M. (2006). Creating an ethical culture. The CPA Journal, 76 (10), 80.

Leap, T. (2008). When bad people rise to the top. MIT Sloan Management Review, 49 (2), 23-28.

Micewski, E., \& Troy, C. (2007). Business ethics: Deontologically revisited. Journal of Business Ethics, $72,17-25$.

Moustakas, C. (1994). Phenomenological research methods. Thousand Oaks, CA: Sage.

Nash, J. (2010). Taking the stress out of work. Risk Management, 57, 42-47.

Pinto, Jonathan, Carrie Leana, \& Frits K. Pil (2008). Corrupt organizations or organizations of corrupt individuals? Two organizational-level corruption phenomena. Academy of Management Review, 33 (3), 685-709.

Prewitt, V. (2003). Leadership development for learning organizations. Leadership \& Organization Development Journal, 24, 58-61.

Rasche, A. (2010). Collaborative governance 2.0. Corporate Governance, 10 (4), 500-511.

Robin, D. (2009). Toward an applied meaning for ethics in business. Journal of Business Ethics, 89, 139-150.

Strier, F. (2007). Stealth compensation. International Journal of Disclosure and Governance, 4, 132144.

Van Buren, H., III, \& Greenwood, M. (2008). Enhancing employee voice: Are voluntary employer-employee partnerships enough? Journal of Business Ethics, 81, 209-221.

Verschoor, C. (2006). Surveys show ethics problems persist. Strategic Finance, 88 (4), 19-20, 61.

Wren, D. (2005). The history of management thought (5th Ed.). Wiley, John \& Sons, Incorporated.

Advised by Sonia Teresinha de Sousa Penin, University of Sao Paulo, Brazil

Received: April 15, 2013

Accepted: June 01, 2013

Tudor Pendiuc

Elena Carmen Lis
Ph.D., Mayor of Pitesti Municipality, Constantin Brancoveanu University, Victoriei Street, no. 24, 110017 Pitesti, Arges County, Romania.

E-mail: tpdoru@gmail.com, cabinetprimar@primariapitesti.ro Website: http://primariapitesti.ro

Ph.D., Counsellor, Pitesti City Hall, Victoriei street, no. 24, Pitesti, Arges County, Romania.

E-mail: ecarmen.prim@yahoo.com
PROBLEMS 